\title{
Economics and Virtue Ethics: Reflections from a Christian Perspective
}

\author{
Published as Chapter 7 in J. Kidwell and S. Doherty (eds.) Theology and Economics: A \\ Christian Vision of the Common Good, New York and Basingstoke: Palgrave MacMillan. \\ 2015
}

\author{
Final version: February 2014
}

Andrew Henley

\section{Introduction}

Pretty much the first thing that undergraduates are taught about economics is that it is a "positive" subject. ${ }^{1}$ In other words, subject to some foundational assumptions about individual economic motivation, it provides a non-normative technical toolkit for understanding how key economic measures such as prices and quantities arise and the relationships between those. One highly popular undergraduate textbook, audaciously entitled An Introduction to Positive Economics, has not been out of print since first publication almost half a century ago. ${ }^{2}$ Economics is in essence a modernist subject, a product of the Enlightenment project to free the individual from higher moral authority or external teleology. It retains very firmly a distinct meta-narrative, derived from the notion of homo oeconomicus, the rational economic individual.

From the perspective of Christian theology the absence of an external teleology in economic analysis is problematic - it confines the subject to the consideration of behaviour and activity of the economic agent that seeks only to further the private well-being of that same economic agent. It implies an essentially static and ahistorical perspective on issues of fairness and justice, ${ }^{3}$ and it largely confines itself to considerations of individual rationality. In short, economics focuses on outcomes of economic behaviour rather than the quality of the behaviour or decisions that might lead to those outcomes. At best these considerations are based on an incomplete understanding of rationality as reasoning or at worst on an understanding of rationality which is circular and devoid of content. Rational behaviour is that which furthers personal satisfaction (although this need not equate to pure egoism), rather than any higher cosmic purpose. But then any actions can imputed as rational, regardless of personal moral purpose or higher moral order.

However, the unanswered question here of "how one should live"4 is hardly a new one - it has been the subject of philosophical enquiry for at least two and a half millennia. In the contemporary world, as individuals, communities and governments grapple with present economic and financial uncertainties, the question of how economic agents should behave is never far from the surface of discussion. And yet contemporary economics appears decreasingly well-equipped to provide answers to this question of what virtuous economic behaviour might look like. Instead normative economic reasoning remains stuck in the sphere of "because we observe $\mathrm{Y}$ and $\mathrm{X}$ is related to $\mathrm{Y}$, this individual/firm/government ought to do this to $\mathrm{X}$ " (and by implication doing "this" would be virtuous). To extend this normative enquiry further in order to encompass external teleological considerations is to ask the question "for what purpose should economic behaviour be directed". Beyond internal goals of aggregated personal satisfaction, this is typically well beyond the scope of contemporary economic discourse.

\footnotetext{
${ }^{1}$ Milton Friedman, "The methodology of positive economics", in Essays in Positive Economics, ed. Milton Friedman (Chicago: University of Chicago Press., 1953), 3-43.

${ }^{2}$ Richard G. Lipsey, An Introduction to Positive Economics, (London: Weidenfield and Nicholson, 1963).

${ }^{3}$ Andrew Hartropp, What is Economic Justice?, (Milton Keynes: Paternoster Press, 2007).

${ }^{4}$ Roger Crisp, How Should One Live: Essays on the Virtues (Oxford: Clarendon Press, 1996).
} 
The remainder of this contribution is a reflection on what might constitute virtuous economic behaviour. I will explore the fiction of "rational economic man" and the implicit conception of virtue within (neo)classical economics, and expose the limited and contradictory nature of that understanding. I will go on to sketch the role for virtue in the development of a Christian perspective on economics, and explore a number of questions that might arise from this. In particular I will reflect on the critical importance of the Christian perspective on the Kingdom of God in providing a teleological and eschatological foundation for an appropriate perspective on economic behaviour.

\section{"Positive" economic analysis and the fiction of homo oeconomicus}

Economics, as an academic discipline, is a product of the Enlightenment project, as exemplified in the philosophy of David Hume and Adam Smith and, in continental Europe, most notably that of Pascal. That project sought a "rationalist" understanding of human nature on the basis of an abandonment of a sense of higher moral order in favour of human nature "as is". Alasdair Macintyre, in his seminal re-evaluation of moral philosophy, describes this project in the following terms:

...the joint effect of the secular rejection of both Protestant and Catholic theology and the scientific and philosophical rejection of Aristotelianism was to eliminate any notion of man-as-he-could-be-if-he-realized-his-telos. Since the whole point of ethics - both as a theoretical and a practical discipline - is to enable man to pass from his present state to his true end, the elimination of any notion of essential human nature and with it the abandonment of any notion of telos leaves behind a moral scheme composed of two remaining elements whose relationship becomes quite unclear. There is on the one hand a certain content for morality: a set of injunctions deprived of their teleological context. There is on the other hand a certain view of untutored-human-nature-as-it-is. Since the moral injunctions were originally at home in a scheme in which their purpose was to correct, improve and educate that human nature, they are clearly not going to be such as could be deduced from true statements about human nature or justified in some other way by appealing to its characteristics. ${ }^{5}$

Although Macintyre may not have had classical Enlightenment economic analysis specifically in his sights, this assessment of the tension which exists ab initio in the discourse of economics is highly perceptive. The origin of a self-interested homo oeconomicus unintentionally working towards the greater societal good originates in Bernard de Mandeville's Fable of the Bees of $1714 .^{6}$

Classical economists in the late $18^{\text {th }}$ and early $19^{\text {th }}$ centuries, and neo-classical economists, from the mid- $19^{\text {th }}$ century onwards, have developed a framework of thought which seeks to deduce conclusions about the appropriateness or otherwise of economic behaviour and activity. This approach has produced a lacuna in economic analysis as to why such conclusions might be appropriate in any moral sense, other than that which is internal to the system of economic reasoning. The abandonment of an external moral telos is implicit in the increasingly sophisticated development of economic analysis over the past 250 years since its publication. This is associated with an emphasis on deductive reasoning, proceeding from human nature "as is".

\footnotetext{
${ }^{5}$ Alasdair MacIntyre, After Virtue, (London: Bloomsbury, 1981, $3^{\text {rd }}$ Ed, 2007) 54-55.

${ }^{6}$ The moral danger of such a radical notion was not lost on John Wesley who remarked a few years later in his diary that "till now I imagined there had never appeared in the world such a book as the works of Machiavel. But de Mandeville goes far beyond it" (quoted by Tomas Sedlacek, Economics of Good and Evil: The Quest for Meaning from Gilgamesh to Wall Street (Oxford: OUP, 2011), 184.
} 
Economics in the $19^{\text {th }}$ century, having arisen alongside the Enlightenment abandonment of belief in created moral order and purpose, readily found an alternative teleology in the utilitarianism of Bentham and Mill, oriented towards the goal of maximising individual utility or satisfaction. It retained, in a diluted form, the Aristotelian notion of eudaimonia (human satisfaction or flourishing) but abandoned any higher purpose for achieving it. It also sustained the Stoic faith in the harmony of nature, re-interpreted as the idea that markets will tend towards equilibrium fuelled by the invisible hand. ${ }^{7}$ Purposeful human economic activity is now directed towards the goal of maximising utility, and therefore the morality of any particular action can be assessed against its capacity to promote or achieve that goal. As Hartropp points out, utilitarianism is, of itself, thoroughly teleological and becomes the standard per se through which economic actions and outcomes are assessed as just or not. ${ }^{8}$ However it is also consequentialist, and can admit no external deontological considerations of the rightness or otherwise of human action. This is regardless of whether those considerations originate from higher ontological considerations of human existence, or from a Kantian moral reasoning independent from reference to higher moral order.

Economic analysis might also be regarded as highly ahistorical - economic agents arrive as Lockian tabulae rasa and reason for themselves without recourse to past wisdom or narrative. In the words of Oliver O’Donovan:

What we call 'consequentialism' (or, less accurately, 'utilitarianism', which is, strictly speaking, a species within the genus) is, at its heart, a programme for robbing historical existence of its terrors by conceiving of history as a kind of human artefact. ${ }^{9}$

In these respects, economics contrasts sharply with other social sciences, in which greater emphasis is placed on inductive thinking - the formulation of provisional hypotheses which are subjected to evaluation using a range of quantitative and qualitative research methods. The understanding of "human-nature-as-it-is" in (neo)classical economics found expression in Mandeville's homo oeconomicus, a "rational" individual seeking the goal of personal satisfaction discounted to the here and now. Homo oeconomicus is, in essence, the embodiment of these principles.

\section{The "virtue" of self-interest in the world of neoclassical economics}

It is well understood that utility (or satisfaction or pleasure) is polymorphous in nature. How can I tell if I would derive more pleasure from eating chicken jalfrezi at my local curry house tomorrow evening, or listening again to Martha Argerich's 1965 recording of Chopin's $3^{\text {rd }}$ piano sonata? Modern neoclassical economics has abstracted from the question of cardinal comparison by focusing on ordinal ranking of preference. As long as I know that Chopin will give me more pleasure than curry, regardless of how much more, and as long as I make consistent choices in the face of more than two alternatives, then rationality remains intact. So the economist's defence here is twofold. Firstly, self-seeking behaviour (regardless of questions of virtue) is a reasonable description of human behaviour, as is. Employing the characterisation of homo oeconomicus need not imply moral assent with all observed economic behaviour. Secondly rational economic behaviour need not imply pure egoism. There is no reason why I may not derive satisfaction from the pleasure or happiness of others. Seeing other members of my family enjoy curry or Chopin may increase my own utility. Whether this permits genuinely altruistic behaviour is, however, another question to be left for reflection elsewhere. As Smith observes in the opening pages of The Theory of Moral Sentiments:

\footnotetext{
${ }^{7}$ Sedlacek, Economics of Good and Evil.

${ }^{8}$ Hartropp, What is Economic Justice?

${ }^{9}$ Oliver O'Donovan, Resurrection and Moral Order: An Outline for Evangelical Ethics (Grand Rapids MI: Eerdmans and Leicester: Apollos, $2^{\text {nd }}$ Ed. 1994)
} 
How selfish soever man may be supposed, there are evidently some principles in his nature, which interest him in the fortune of others, and render their happiness necessary to him, though he derives nothing from it except the pleasure of seeing it. ${ }^{10}$

But no amount of advance psychological introspection may actually answer the question of exactly where I expect to gain most satisfaction. Rational choice is revealed by ex post preferences, which in turn are deemed to be rational, providing they remain consistent and independent of the choices of others.

In a strict sense, for the economist, virtuous behaviour is behaviour that satisfies the axioms of neoclassical consumer preference theory, since that will, by construction, result in the greatest good for the greatest number. It remains, however, a matter of philosophical debate as to whether such a statement is meaningful. Some recent authors, most notably Deidre McCloskey ${ }^{11}$, have argued persuasively that market-based capitalist economies can be regarded as promoting virtuous behaviour, in the Aristotelian sense that this promotes eudaimonia. Such behaviour need not be solely self-interested:

It is sometimes said that economists regard it as "natural" or "normal", and in some sense even right, that man should be governed only by selfish motives; this opinion may however be dismissed at once as a popular error, which finds no support in the teaching or practice of the best economists. ${ }^{12}$

For the neoclassical economist, the argument that self-interest (although not necessarily the same as selfishness) is virtuous has resonance. The "private vice" of self-interested behaviour is virtuous because, through the mechanism of the Smithian "invisible hand", such behaviour promotes the "public virtue" of the common good. As Smith famously states:

It is not from the benevolence of the butcher, the brewer, or the baker that we expect our dinner, but from their regard to their own interest. We address ourselves, not to their humanity, but to their self-love, and never talk to them of our own necessities, but of their advantages. ${ }^{13}$

A failure to act in a manner consistent with a focus on outcome could result in misallocation of economic resource. Productive inefficiencies follow because resources are not allocated to their best (i.e. most profitable) use. Prices for some goods are higher than they would otherwise be, and the concomitant reduction in output leads to under-employment of productive capacity, perhaps particularly labour and skills. The "virtuous" pursuit of self-interest by economic agents will correct such misallocations and propel the economy back towards optimality.

"Market failures" arise for various reasons -but it is also "virtuous" self-interested behaviour on the part of others that creates the potential for the correction of market failure. Sometimes public intervention may be required, for example, to regulate monopolistic markets or address market "externalities" where private and social costs and benefits diverge. "Virtuous" selfinterest is pursued in ignorance, wilful or otherwise, of the costs imposed on others (for example pollution), highlighting the point that such market failures may typically arise from knowledge asymmetries. The pursuit of self-interest may lead to excessive risk taking because the costs of that risk have been transferred to a third party, typically through an insurance contract. Such "moral hazard" behaviour is aptly named, since it creates an incentive to behaviour in a less than virtuous

\footnotetext{
${ }^{10}$ Adam Smith, The Theory of Moral Sentiments (London and Edinburgh, 1759), Chapter 1.

11 Deirdre McCloskey, The Bourgeois Virtues: Ethics for an Age of Commerce (Chicago: Chicago University Press, 2006).

12 Alfred Marshall, Principles of Economics (London: Macmillan, 1890).

${ }^{13}$ Adam Smith, An Inquiry into the Nature and Causes of the Wealth of Nations, (London, 1776) Book 1, Chap. $2,19$.
} 
manner, whether it be driving one's car recklessly, or failing to account adequately for risk in a financial market transaction.

This discussion has highlighted the apparent coincidence between the pursuit of self-interest and virtuous behaviour in the neoclassical understanding of the market economy. But in a strict sense we have no way of verifying whether the actions of economic agents are indeed rational and therefore, within the confines of neoclassical economies, virtuous or just. Counterfactual observation is, by definition, impossible. However where recognisable market failures do occur, the balance between actions which promote the greater good and those which do not may be very fine, and therefore "virtuous" corrective action by others (including governments) is justified.

\section{Virtue or pleonoxia?}

The discussion thus far has highlighted the problematic task of trying to interpret appropriate economic behaviour in terms of virtue, while remaining within the neoclassical economic framework. The Enlightenment economic philosophy of the classical economists (Adam Smith, David Ricardo and others) with its strong narrative on why economic agents behave in a particular way may be regarded as trying, in some sense, to cling to an Aristotelian basis for human action. Indeed Sedlacek ${ }^{14}$ considers economic thought to have begun with Aristotle, perhaps the first of the ancient philosophers to focus attention on issues such as productive and unproductive activity, and the sources of market failure outlined above. For Aristotle the economic problem was that of optimising good. The issues here are in defining "good", and in deciding what is optimal. For Aristotle the optimum is not the maximum but a behavioural "mean" tempered by virtues such as temperance and continence (moderation). But by reinterpreting Aristotelian eudaimonia as the utilitarian notion of "greatest good (utility) for the greatest number", and, by switching the objective from optimisation to maximisation, the neoclassical economic analysis of the later $19^{\text {th }}$ century has in effect turned a blind eye to questions of the quality of behaviour or actions that might lead to human wellbeing. Thus it in effect abandoned any conception of what is virtuous, in favour of a sole focus on consequence.

At the heart of Alasdair Macintyre's re-evaluation is a trenchant criticism of the philosophy of contemporary social science. ${ }^{15}$ Macintyre is, in particular, highly sceptical of the view that postenlightenment thinking can construct rational predictions of the behaviour of economies and organizations and from those infer programmes to manage them efficiently. This follows from the impossibility of advance measurement of satisfaction and therefore the inherent unpredictability of human action. This creates a tension between the desire to predict the actions and behaviour of others and retain the freedom to act and remain unknowable in the sense that our lives are not merely the "creations of other people's projects" (p. 104). In this regard Macintyre appeals to the Machiavellian notion of "fortuna" and the unpredictability of the world. Contemporary economics has developed sophisticated conceptual and analytical tools to deal with uncertainty, allowing theoretical advancement and practical modelling solutions. However, without digressing to discuss these in detail, they remain inherently flawed in a moral philosophical sense because they remain wedded to an underlying deterministic-consequentialist view of the world. The key issue is that a rationalist approach to economic management is doomed to failure because it ignores the unpredictability of human behaviour. The modern social and political world is hostile to

\footnotetext{
${ }^{14}$ Sedlacek, Economics of Good and Evil.

${ }^{15}$ MacIntyre, After Virtue.
} 
considerations of virtue, and creates intractable disagreement about how to act, because the incommensurability of different positions cannot be rationally resolved. ${ }^{16}$

Economists are often criticised for seeking to extend to analysis of the market into an ever widening range of human activity and experience (for example, crime, marriage). ${ }^{17}$ For Macintyre this reflects the marginalization of practices (sport, art, music, academic inquiry), and therefore the goods that are internal to them in favour of external goods such as money and status. Work becomes the means to external goods rather than a practice involving the exercise of virtues in pursuit on internal goods such as personal fulfilment, knowledge and skill. ${ }^{18}$ The transfer of activity from within the household or family to the outside market undermines virtue in favour of pleonoxia (that is, greed or covetousness). Pleonoxia, regarded by Aristotle as a vice, becomes the driving force of modern human work effort. ${ }^{19}$

The case is therefore made to return to a prescriptive analysis of economic behaviour, which addresses the important question of how to behave. Once one retreats from the "to what end" question towards the "how" question, then the reintegration of virtue in understanding economic behaviour becomes possible. But what sort of virtue?

\section{Christian perspective on virtue and Christian reflection on economics}

The central preoccupation of Aristotle's Nicomachean Ethics ${ }^{20}$ is eudaimonia, commonly translated as happiness. Aristotle's conception of happiness is as a state of self-sufficiency that protects against the vicissitudes of the world. In the Aristotelian world virtues are the form of happiness - not the means to happiness. ${ }^{21}$ The happy person is a virtuous one, not merely the one who pursues virtuous behaviour. Aristotle's characterisation of the magnanimous man with a deep voice and a steady gait, exercising self-control and prudence, might seem archaic to the modern mind. There is a strong strand of "new-Aristotelian" work in recent economic work that wants to return to thinking about psychological happiness as a human goal. ${ }^{22}$ However, this new literature ultimately finds it difficult to escape from utilitarian analysis - happiness is measured by asking people whether they are happy or not (on a scale of 1 to $n$ ). Whilst it might have something to say about what people think, it has little to say about how they behave.

But more fundamentally, while the Christian theologian might not necessarily dismiss psychological happiness as a desirable human state, an understanding of how it might be achieved is profoundly different. Christian fulfilment comes from knowledge of Jesus Christ, formation of our lives in response to His love through the power of the Holy Spirit, and in the eschatological hope sealed in the resurrection. Therefore an understanding of virtue from a Christian perspective must stem from that telos. ${ }^{23}$ As O'Donovan makes plain, there can be no Christian understanding of ethics apart from an understanding of the created moral order in the universe, from creation to

\footnotetext{
${ }^{16}$ Andrew Mason, "MacIntyre on modernity and how it has marginalised the virtues", in How Should One Live, ed. Crisp, 191-210.

${ }^{17}$ See, for example, Gary S. Becker, Gary S. (1993), "Nobel lecture: the economic way of looking at behaviour", Journal of Political Economy,101, no. 3 (1993) 385-409; Steven D. Levitt and Stephen J. Dubner, Freakonomics: A rogue economist explains the hidden side of everything (London: Allen Lane, 2005).

18 Mason, "MacIntyre on modernity".

${ }^{19}$ MacIntyre, After Virtue, 227.

${ }^{20}$ Aristotle, The Nicomachean Ethics, trans. David Ross (Oxford: OUP Oxford World's Classics, 1980, revised 2007).

${ }^{21}$ Stanley Hauerwas and Charles Pinches, Christians among the Virtues: Theological conversations with ancient and modern ethics (Notre Dame IN: University of Notre Dame Press, 1997).

${ }^{22}$ Richard Layard, Happiness: Lessons from a New Science (Harmondsworth: Penguin, $2^{\text {nd }}$ Ed, 2011).

${ }^{23}$ Tom Wright, Virtue Reborn (London: SPCK, 2010)
} 
redemption. ${ }^{24}$ Wright argues that the early Church held a clear sense of the vision implied by this understanding of Christian telos:

The early Christians held out a breathtaking, radical vision of the ultimate goal of all things: the new heavens and the new earth, the renewal of all things, the new Jerusalem "coming down from heaven to earth" (Revelation 21.2), a world flooded with the joy and justice of the God who made it in the first place. The question must then be asked: What place, and what role, will human beings have within this new world? Only when we answer that question can we begin to understand the virtues by which, in the present time, our characters can be formed. What were we made for, and how can we learn that future language here and now? $?^{25}$

The Christian vocation in the created order is plain in the narrative of both the Old Testament and the New. Psalm 8 speaks of the supremacy of the Creator, and yet is awestruck that God has willed that humankind, His creation, should have purpose within that order. Paul, in Romans 8 , observes that God's purpose is that creation itself, humankind included as the firstfruits of the Spirit, will be liberated from present bondage and "obtain the freedom of the glory of the Children of God" (Rom 8.21, ESV). The truth of the resurrection is integral to the telos, as made clear by a further quotation from Oliver O'Donovan:

So the resurrection of Christ directs our attention back to the creation which it vindicates. But we must understand 'creation' not merely as the raw material out of which the world as we know it is composed, but as the order and coherence in which it is composed. To speak of the resurrection of creation would be meaningless if creation were no more than so much undifferentiated energy. Such a proclamation can have a point only if it assures us that the very thing that God has made will continue and flourish. ${ }^{26}$

Order is both description and end, 'generic' and 'teleological'. Thus the end of economic activity is to further the moral purpose of God in bringing forward the Kingdom of God and in taking up this way of thinking, a more limited Aristotelian conception in which teleological ordering is a purely natural ordering is insufficient. The Scholastic theologians, most notably Thomas Aquinas, understood this point. For Aquinas, the rediscovery of Aristotle's focus on the external world, combined with a distinctive Christian focus, shifted emphasis from the purely spiritual world to that of creation - a creation that, while still bound in sin, was created good and will ultimately be restored to that goodness. Those who enjoy that creation, even in its current imperfection, experience the common grace of the Creator. If a good God created ex nihilo, then the material world too must be good. In the words of Tomas Sedlacek, "From this viewpoint, matter, reality, and this world represent good - it is therefore worth dealing with, worth improving, and worth addressing." 27 But crucially the economic world is part of that created moral order, and it too is part of this telos. A Christian re-construction or re-interpretation of economics must begin from this point.

The notion of virtue, re-interpreted as working towards the achievement of Christ-likeness, has been problematic in the past in theology, particularly Protestant or Reformed theology. Indeed Augustine argued that "pagan" (i.e. Aristotelian) notions of virtue were nothing less than sin, unless radically transformed by Christian understanding of love. Traditional protestant interpretations may have expressed caution on the prominence given to virtue, concerned not to lapse into a theology of

\footnotetext{
${ }^{24}$ O'Donovan, Resurrection and Moral Order.

${ }^{25}$ Wright, Virtue Reborn, 68 (my italics).

${ }^{26}$ O'Donovan, Resurrection and Moral Order, 31.

${ }^{27}$ Sedlacek, Economics of Good and Evil, 137.
} 
salvation by work. ${ }^{28}$ Modern thinking appears to have moved on from this position. Salvation is not earned by virtuous economic behaviour; a calling to Christ-likeness is fulfilled by seeking the Kingdom of God in economic and social life. The implications for the understanding of economic activity and behaviour here are twofold. The first is the need to affirm that the economic activity falls within the realm of the Kingdom of God, a Kingdom which is both an eschatological hope and an ontological reality. Cray describes this with the phrase "presence of the future". ${ }^{29}$ The second is that the transformation of character $^{30}$ applies to economic behaviour as much as to any other form of human behaviour. For theologians such as Hauerwas and Wright a Christian re-examination and transformation of an ancient focus on virtue is commended.

Contemporary discussion of economics for a Christian perspective has rarely, if ever, made explicit mention of Christian virtue. However, by no means, is this to say that this discussion has not addressed important questions of how economic agents ought to behave. ${ }^{31}$ Market incentives might be harnessed to encourage virtuous behaviour. ${ }^{32}$ Various approaches to the integration of Christian theology and economics are possible. ${ }^{33}$ Each has grounds for recommending itself, and each has its proponents. However, each is also problematic. A first approach attempts to "run with" modern economic analysis, implicitly arguing alongside McCloskey ${ }^{34}$ and others that "bourgeois" virtue in the pursuit of wealth, industriousness and personal responsibility are commendable. A second approach is more radical, seeking to construct an agenda for economics on the basis of biblical principles of behaviour in both Old and New Testaments. It offers greatest potential for the incorporation of biblical perspective on virtue. However, it often leaves wide open a range of difficult questions about biblical hermeneutics, and may stray into the derivation of economic principles from very specific Old Testament legal provision. A third approach, favoured by Hay and others, seeks a critical or "subversive" approach, but typically appears frustratingly incomplete and provisional.

Alongside these approaches runs a further approach that seeks to explore and apply a Christian theological perspective on economic justice. ${ }^{35}$ This approach focuses on understanding the biblical concept of justice (righteousness) and applying it to the contemporary economic world. The connection here with virtue is readily apparent. Firstly, justice (dikaiosuné) is central to the Aristotelian discourse on ethics, and described as a key virtue. Secondly, justice is conceived by both Aristotle and by the biblical writers as dynamic notion. In the Aristotelian schema virtue is both a means and an end. The Bible, too, exhorts its readers to "do justice" (Is 56.1) or "see justice done" (2Cor 7.11). Acting with justice concerns behaviour, as much as outcomes. However, for Christians justice is more - it is a Christological conception (Hartropp, 2007). Jesus is the fulfilment of justice/righteousness (Mt 3.15) and therefore the pattern and standard.

\footnotetext{
${ }^{28}$ Hauerwas and Pinches, Christians among the Virtues; Graham Tomlin, Spiritual Fitness: Christian character in a consumer culture (London: Continuum, 2006).

${ }^{29}$ Graham Cray, Disciples and Citizens: a vision for distinctive living (Nottingham: Inter-Varsity Press, 2007).

${ }^{30}$ Tomlin, Spiritual Fitness; Cray, Disciplines and Citizens; Wright, Virtue Reborn.

${ }^{31}$ Donald Hay, "On being a Christian economist" in, Christianity and the Culture of Economics, eds. Donald Hay and Alan Kreider (Cardiff: University of Wales Press, 2001) 166-190.

32 J. David Richardson, "Frontiers in economics and Christian scholarship", Christian Scholar's Review, 17 (June 1988): 381-400.

${ }^{33}$ Hay, "On being a Christian economist".

${ }^{34}$ McCloskey, The Bourgeois Virtues.

${ }^{35}$ Examples include: National Conference of Catholic Bishops (1986), Economic Justice for All: Pastoral letter on Catholic social teaching and the US economy (Washington DC: United States Catholic Conference, 1986, reprinted in Catholic Social Thought: The Documentary Heritage, eds. David J. O'Brien ad Thomas A. Shannon (Maryknoll NY: Orbis, 1992); Rebecca M. Blank, Do Justice: Linking Christian faith and modern economic life (Cleveland OH: United Church Press, 1992); E. Calvin Beisner, (1994), "Justice and poverty: two views contrasted", in Christianity and Economics in the Post-Cold War Era, eds. Herbert Schlossberg, Vinay Samuel and Ronald J. Sider (Grand Rapids MI: Eerdmans, 1994) 57-80; Hartropp, What is Economic Justice?
} 
Here there is a stark contrast with the contemporary secular economic understanding of justice, which is static, describing not behaviour or personal embodiment but an outcome in which reward or procedure is deemed to be fair. ${ }^{36}$ Furthermore, if we derive a notion of justice from Jesus' embodiment of the moral law (summarised as loving God and neighbour) then justice is an both an activity and a state, and cannot be reduced to a code of moral conduct. To quote Oliver O'Donovan for a third time:

If...a code of moral rules is no more than a cultural form through which we communicate knowledge of the created order which is itself a whole, then it is clear that our ordering-principles will be something rather more significant than mere procedural rules-for-applying-rules. They will provide insight into what the rules are really about. ${ }^{37}$

It might be therefore argued that it is not appropriate to attempt to derive a set of rules or principles for economic life from the foundation of Old Testament economic law, as some recent attempts by economists try to achieve. Rather Christian economists need to understand underlying moral order, and frame economics in terms of "how one should live" rather than by the observation of "how economic agents behave".

\section{Economic virtue and the Kingdom of God}

So what might this mean in practice for economics? One observation to make is that it is wildly optimistic to "do justice" to answering this question within a few short paragraphs. This is a challenge that calls for a great deal of further work on the part of economists and Christian ethicists, hopefully working in concert. So, what follows is intended to be a preliminary overview, and an identification ofr four particular questions that remain for further discussion. These are: what aspects of Christian virtue are salient; isn't the hope of virtuous voluntary economic behaviour over-idealistic; which specific virtues should be underpin theological reflection on economics; and does a focus on individual virtue in economic behaviour obviate the need for government regulation?

The first question is to ask what aspects of Christian virtue have particular salience for economic behaviour and activity. The Scholastics, notably Aquinas, tabulate the virtues as if to present an exhaustive list. The New Testament material does not imply this, but rather focuses on the transformation of Christian character. However, there is a parallel with Aristotle's view that the virtues are to be practiced, and that it is only through repeated exercise that they become inherent to an individual's character (1Cor 9.25, Eph 6.4, 1 Tim 4.8, 2 Tim 3.16). Indeed the "training and fitness" in regard to Christian character and virtue is specifically commended by some writers (for example Tomlin, 2006).

The process of answering this question requires a focus on the Christian task of bringing forward the presence of the future Kingdom of God, through particular attention to the task of demonstrating the economic aspects of that Kingdom. What will characterise that Kingdom? It will be an economy of care and responsibility, an economy of creativity, and an economy where actions as well as outcomes are just (deontology and teleology). Certainly this is likely to entail a full range of virtue, as described in the various taxonomies in the New Testament, particularly Pauline, material (the "theological virtues" of 1 Cor 13, as well as the encouragement for holy living in Col. 3, the fruit of the Spirit listed in Gal 5 and the avoidance of the "vices" as listed in Eph 4 and Col. 3 ). And, as such, the principles underlying this economy are likely to stand in stark contrast to those

\footnotetext{
${ }^{36}$ This is perhaps most notably espoused in the work of John Rawls, for example "Justice as Fairness: Political not Metaphysical," Philosophy and Public Affairs 14 (Summer 1985): 223-251.

${ }^{37}$ O'Donovan, Resurrection and Moral Order, 203.
} 
which underpin modern neoclassical economic analysis, with its "internal" teleology and absence of deontology. One the other hand these principles may not be as distinct from much of the practice of economic behaviour in the world today, where despite the attractiveness of homo oeconomicus, we do observe, at least some of the time, economic relationships which are based on trust, faithfulness, honesty, restraint (temperance) and care, to name but some of the traditional virtues of the Greek philosophers, the early fathers and the Scholastics.

However, despite this assertion, others may counter with a second question, namely isn't it hopelessly utopian to expect virtuous economic behaviour to arise on a voluntary basis? The various writers of the New Testament epistles do not appear to think so. One could turn this question round and ask whether the post-Enlightenment economic project is unrealistically pessimistic in anticipating that all human economic behaviour is motivated by self-interest? Indeed, it has already been noted that economics is criticised for pursuing a form of intellectual hegemony, in which all forms of human social encounter are sought to be brought under the ambit of economic motivation and analysis. Within academe, economists themselves are frequently criticised for creating around themselves an aura of intellectual superiority that admits limited engagement with other methodological and philosophical perspectives. The study of economics is also criticised for inculcating within its students a self-interested mind-set that undermines altruistic values and cooperative behaviour. ${ }^{38}$

The presence of virtue and the development of virtuous character in the conduct of economic affairs may indicate the operation of common grace in the world, but is it realistic to seek to encourage a framework for virtue based on the eschatological hope of the Kingdom of God to be adopted by both Christian believers and non-believers alike? To the mediaeval mind of the Scholastics this question would hardly have arisen, but it does impress in today's secular, multicultural world. Christians are therefore often reluctant to argue a strongly theological basis to their proposals for social and economic policy. It is possible to appeal to an Aristotelian basis for ethics in the economic sphere. In the field of business ethics this is often done - concepts of virtue and common good are appealing to those who seek to introduce a strong sense of personal responsibility in business affairs, in preference to some bland notion of corporate social responsibility informed by "enlightened corporate self-interest". I would argue that a virtue-based economics has to be applied universally. This is not only because of the doctrine of common grace, but also for the more prosaic reason that a "separatist" approach may suffer from a form of Gresham's Law or adverse selection effect. Non-virtuous agents may drive the virtuous from the market. This effect is in fact well understood in economics - mostly through the seminal work of George Akerlof who famously describes failure in the market for lemons (second-hand cars) ${ }^{39}$ - and is often used to justify intervention or regulation.

So, a third question may arise as to which specific virtues would underpin a Christian theological perspective on economic behaviour? Here one might return to the argument that to produce an exhaustive taxonomy of economic virtue is surely to miss the point that virtue is about "training in righteousness" (1 Tim 3.16). However virtues such as trust (c.f. faithfulness), honesty, creativity, stewardship (c.f. temperance), and forbearance to exploit others (c.f. self-control) can all be commended in the conduct of economic affairs. Undoubtedly, however, a key economic virtue is justice. A theological perspective on justice is essential to a Christian "reinterpretation" of economics. ${ }^{40}$

\footnotetext{
${ }^{38}$ As an example, see Robert H. Frank, Thomas D. Gilovich, and Dennis T. Regan, "Does studying economics inhibit cooperation?" Journal of Economic Perspectives, 7 (1993): 159-171. However others dispute this criticism,

${ }^{39}$ George A. Akerlof, "The market for "lemons": quality uncertainty and the market mechanism," Quarterly Journal of Economics, 84 no. 3 (1970): 488-500.

${ }^{40}$ Hartropp, What is Economic Justice?
} 
I return to Alasdair Macintyre a final time in order to highlight an important aspect of virtue. Macintyre defines a virtue as "an acquired human quality the possession and exercise of which tends to enable us to achieve those goods which are internal to practises and the lack of which effectively prevents us from achieving any such goods." socially co-operative human activity through which participants are able to realise internal goods (personal fulfilment) in pursuing excellence in that activity. So these might include, for example, scientific and innovative endeavour, artistic and sporting pursuits, or collective community service. A theological perspective might view such practices are sharing in the creative activity of the Creator. Practices define relationships with others. These practices might well include economic endeavour designed to meet the needs of others. Because practices are in essence relational then, therefore, virtue is also fundamentally about relationship. A simple reflection on the transitive nature of virtuous behaviour illustrates this: "honesty towards whom?", "justice for whom?" "care of whom"? etc. Economic analyses, which fail to take account of the temporal dynamics of human relationships, and the manner in which virtue may develop through those relationships, will be partial and incomplete. It will fail to recognise that the telos of economic activity that may emerge could be very different from that deduced from the a-historical and utilitarian orthodox economic model.

Finally a fourth question returns to the issue of voluntarism. Does a focus on personal or communal virtue in economic behaviour let government "off the hook"? This question concerns the focus or agenda for any attempt to reconstruct economics around an emphasis on virtue. In business ethics, virtue-based approaches focus on the quality of the behaviour or decision-making of individuals, or perhaps groups of individuals acting in concert, such as the board of a corporate organization. The external legal framework within which those decisions are framed is taken as a "given". In contemporary societies economic activity is heavily circumscribed by a range of external institutions and government interventions. These include not only an external framework of contract law and the institutions to enforce that, but also a wide range of government regulation, designed to protect to varying degrees the interests of "stakeholders" - consumers, employees, investors. Often the justification for regulation is to protect individuals against market failures of the kind described earlier, although sometimes it may be to protect individuals from other forms of harm or exploitation. In broad terms these activities might be framed in terms of society "doing justice" to those who may be vulnerable in different economic circumstances. Governments raise taxes and disburse those taxes to support a wide range of "programmes" which might not otherwise be adequately provided, including health and social care, education, infrastructure, public order and defence. Governments, in modern economies, also operate and regulate financial systems to provide fiduciary currency, and may manipulate monetary policy in pursuit of macroeconomic objectives. The question for discussion here is the extent to which considerations of virtue might guide such activity. To the extent that justice is a key virtue, then virtue has a part to play. However, there will need to "mechanisms" in place to ensure that public institutions through their corporate action can give expression to that virtue. Should government operate to exhort or even incentivise virtuous behaviour? Formal incentivisation of virtue may be self-defeating in the sense that once an external agency "pushes" individuals towards virtuous behaviour, then that behaviour ceases to be virtuous However, it is not sufficient to argue that a virtue-based approach to economics pushes all legitimate consideration of the quality of economic behaviour onto the individual economic agent, and that economic problems can simply be solved through individual virtuous action. The Kingdom of God is a kingdom - in fact it is the highest expression of any form of kingdom or governance. Governance implies moral order; it does not imply a form of voluntarist "anarchy".

\footnotetext{
${ }^{41}$ MacIntyre, After Virtue, 191.
} 
In this chapter, I have argued that a recent revival of interest from contemporary theologians in virtue ethics has much to contribute to a critique of modern economics. Classical and neoclassical economic analysis is founded on enlightenment thinking, and in particularly on a utilitarian philosophy which replaces an external teleology with one which is internal and "circular". Consequently it is unable to pronounce with any authority on normative questions concerning the quality of economic behaviour and actions. For Christian economists this is well understood. However a Christian perspective on virtue ethics has to proceed from a teleology which is focused on the "present future" of the Kingdom of God and not on a more generic Aristotelian notion of common good or eudaimonia. I conclude with a brief exploration of considerations of virtue in two highly topical contemporary areas.

The financial crisis of 2008 onwards has been extensively analysed. ${ }^{42}$ Much of that analysis has focused on the unravelling of inadequate government regulation and the consequences of mistaken macro-economic policy, which allowed corporate and government debt to spiral, and forced governments to push the process of re-adjustment and "re-capitalisation" onto their populations. The role of personal responsibility has also figured in the analysis and discussion, but more often than not it figures as public criticism of key figures in leadership, including bankers and politicians, and levels of personal accountability. In the case of the banking industry, discussion has focused around the apparently weak relationship between performance and reward.

These concerns sidestep more fundamental questions about whether the crisis resulted from "technical" failure or moral failure. A Christian perspective must take account of the moral or ethical questions underlying the crisis. Recklessness on the part of economic agents was apparent in lending strategies, in attitudes towards risk management (notably in strategies to pass on responsibility for risk through "securitization"), and in political-economic management (for example in the self-belief that the business-cycle appeared to have been abolished). As bad debt spread through the securitization process, financial systems ground to a halt because trust between financial institutions evaporated. A virtue-based approach would not only focus on underlying issues of justice, but also on the absence of forbearance, prudence and, as the crisis unravelled, trust. Technical education in the intricacies of financial markets must sit alongside a moral education that seeks to instil virtuous character on the part of bankers. Education in financial literacy needs to address not only questions of how mortgages and other financial products can assist young people, but also the importance of prudence for borrowers, as well as for lenders.

Global climate change is a crisis of longer gestation, and one which will continue to be present well after financial institutions have been recapitalised, government fiscal balances restored and the balance sheets of households re-established in favour of saving rather than borrowing. If one accepts the weight of evidence on global average temperature rise and that this is anthropogenic, then present generations are presuming on the inheritance their successors in failing to steward God's creation so that it remains able to sustain life into the future. Economic analysis of the consequences of climate change focuses on technical solutions, for example the implementation of incentive mechanisms to adapt economic behaviour (as described, for example, in the Stern Report $\left.^{43}\right)$.

Experience of changing economic behaviour in order to prevent damage to the natural environment suggests that marginal adjustments in economic incentives may be effective. This is, for example, illustrated by the adoption of unleaded petrol following adjustments to petrol excise duty in the late $1980 \mathrm{~s}$, or by the installation of solar photo-voltaic panels in response to attractive

\footnotetext{
${ }^{42}$ For a Christian economist's perspective, see Philip E. Davis, The Crisis and the Kingdom: Economics, scripture and the global financial crisis,(Eugene, OR: Cascade Books, 2012).

${ }^{43}$ Nicholas Stern, The Economics of Climate Change: The Stern Review, Cambridge: CUP, 2007.
} 
"feed-in" tariffs much more recently. However, here "stewardship" behaviour is motivated by the telos of self-interest, and policy design proceeds from an uncritical acceptance of the utilitarian economic paradigm. Concern to change economic behaviour in response to climate change is motivated for many by deontological concerns. That concern also relates to the created order. Personal strategies to reduce "carbon footprint" are motivated by virtues of stewardship and justice. Concern for the impact of climate change on the global poor and on the natural order is greater teleological significance than personal self-interest. Impact of personal behaviour on others highlights the relational aspect of a virtue-based approach. However, the question remains as to whether the "pull" of such virtuous behaviour is sufficiently strong to effect economic change. The juxtaposition of appealing to "better virtue" or "baser self-interest" here illustrates the inherent tension between seeking to develop policy on the basis of how economic agents ought to behave or on the pragmatic basis of accepting economic behaviour as it appears to be. A Christian theological basis for economics ought not to accept the pessimism of the latter, but reflect on the economic implications of the optimism of the Kingdom of God in the present. 